\title{
Prevalence of Hepatitis $C$ Virus in Tuberculosis Patients: A Systematic Review and Meta-Analysis
}

\author{
Meysam Behzadifar ${ }^{*}$, Sanaz Heydarvand ${ }^{2}$, Masoud Behzadifar ${ }^{3}$, Nicola Luigi \\ Bragazzi $^{4}$
}

\begin{abstract}
OPEN ACCESS
Citation: Meysam Behzadifar, Sanaz Heydarvand, Masoud Behzadifar, Nicola Luigi Bragazzi, Meysam Behzadifar, Sanaz Heydarvand, Masoud Behzadifar, Nicola Luigi Bragazzi. Prevalence of Hepatitis C Virus in Tuberculosis Patients: A Systematic Review and Meta-Analysis. Ethiop J Health Sci. 2018;29(1):945. doi:http://dx.doi.org/10.4314/ejhs.v29i1.17 Received: June 28, 2018

Accepted: July 15, 2018

Published: January 1, 2019

Copyright: (C) 2018 Meysam Behzadifar,

B. et al. This is an open access article distributed under the terms of the Creative Commons Attribution License, which permits unrestricted use, distribution, and reproduction in any medium, provided the original author and source are credited. Funding: Bona District Health Bureau and Abem private clinic.

Competing Interests: The authors declare that this manuscript was approved by all authors in its form and that no competing interest exists.

Affiliation and Correspondence:

${ }^{1}$ Hepatitis Research Center, Lorestan University of Medical Sciences, Khorramabad, Iran

${ }^{2}$ Bahrami Pediatric Hospital, Tehran University of Medical Sciences, Tehran, Iran

${ }^{3}$ Health Management and Economics Research Center, Iran University of Medical Sciences, Tehran, Iran ${ }^{4}$ School of Public Health, Department of Health Sciences (DISSAL), University of Genoa, Genoa, Italy *Email:behzadifar.m@tak.iums.ac.ir, masudbehzadifar@gmail.com
\end{abstract}

\begin{abstract}
BACKGROUND: Infection with Hepatitis C Virus (HCV) increases the hepatotoxicity of anti-tuberculosis drugs. The purpose of this systematic review and meta-analysis is to determine the prevalence of $\mathrm{HCV}$ infection in patients with tuberculosis (TB).

METHODS: PubMed/MEDLINE, ISI/Web of Sciences, CINAHL, EMBASE, the Cochrane Library and Scopus were searched from January 2000 to March 2018. The overall prevalence of $\mathrm{HCV}$ in patients with $T B$ was calculated using the random-effect model with 95\% confidence interval (CI). To evaluate heterogeneity, $I^{2}$ test was used. Egger's regression test was utilized to check publication bias.

RESULTS: Twenty-one articles were selected for the final analysis based on the inclusion/exclusion criteria. A total of 15,542 patients with $\mathrm{TB}$ participated in the studies. The overall prevalence of $\mathrm{HCV}$ infection in patients with TB was 7\% [95\%CI: 6-9]. Subgroup analysis revealed that diagnostic test $(P=0.0039)$, geographical background $(P=0.0076)$ and gender distribution $(P=0.0672)$ were statistically significant moderators. Men had a higher risk for HCV than women (Odds Ratio, $O R=2.02$; 95\%CI: 1.28-3.18).

CONCLUSION: The results of this study highlighted the importance of screening $\mathrm{HCV}$ in TB patients. Knowing whether $H C V$ is present or not in these patients can be helpful in effectively treating them.

KEYWORDS: Prevalence, hepatitis C virus, tuberculosis, systematic review, meta-analysis

\section{INRODUCTION}

Tuberculosis (TB) is recognized as one of the most important public health challenges following acquired immune deficiency syndrome (AIDS), the second leading cause of death in the world. Each year, countries allocate a significant amount of resources in order to properly cope with this disease $(1,2)$. In its latest available report, the World Health Organization (WHO) estimated that around 10.4 million people in the world had TB in 2016. The highest incidence $(45 \%)$ was in South-East Asia, followed by, Africa (25\%), Western Pacific Region (17\%), Eastern Mediterranean Region (7\%) and Europe and the Americas (3\%) (3).
\end{abstract}


Hepatitis C Virus (HCV) is another major health problem both in developing and developed countries, which can cause acute and chronic illness in people. About $1.1 \%$ of the world's population was infected with $\mathrm{HCV}$ : 80 million had chronic HCV and 495,000 died in $2015(4,5)$. Most people infected with $\mathrm{HCV}$ are not aware of their illness, which makes them at risk for liver cirrhosis or cancer $(6,7)$.

With regard to the prevalence of $\mathrm{HCV}$ in patients with TB and the impact that the infection has on these patients, few studies have been conducted worldwide, and there is still little evidence concerning this topic (8). One of the major, clinically relevant side effects in the treatment of TB is hepatotoxicity, which disrupts the treatment process and may lead to discontinuation of the patient's treatment $(9,10)$. Hepatotoxicity is one of the side effects of Directly Observed Treatment, Short-Course (DOTS), first line drugs, which include Rifampin, Pyrazinamide, and Isoniazid (11-16). Infection with HCV increases the hepatotoxicity of anti-TB drugs, and patients with TB should be tested for HCV before they start treatment (9).

The aim of this study is to provide a detailed summary of the prevalence of $\mathrm{HCV}$ in patients with TB. We believe that reducing the effects of hepatitis $\mathrm{C}$ infection in these patients can be an achievable goal when there is precise data on its prevalence. In order to provide evidence for physicians and healthcare policy- and decisionmakers, the aim of this systematic review and meta-analysis is to determine the prevalence of $\mathrm{HCV}$ infection in patients with TB.

\section{MATERIALS AND METHODS}

Search strategy for identifying relevant studies: PubMed/MEDLINE, ISI/Web of Sciences (WoS), CINAHL, EMBASE, the Cochrane Library and Scopus databases were searched from January 2000 to March 2018. Search strategy was based on the following string of keywords: (prevalence OR frequency OR epidemiology OR seroprevalence OR seroepidemiology OR proportion OR rate) AND (hepatitis $\mathrm{C}$ virus OR HCV OR viral hepatitis OR viral hepatitis C) AND (tuberculosis OR Mycobacterium tuberculosis OR mycobacterium OR TB). Also, reference lists of included studies were reviewed and scanned for possible relevant studies.

Inclusion criteria: Studies were included if they were epidemiological studies designed as crosssectional, longitudinal or case-control studies. They were retained if they examined the prevalence of $\mathrm{HCV}$ in patients with $\mathrm{TB}$, were published in English, had sufficient data to allow the calculation of the prevalence, and used validated, standardized diagnostic tests such as linked immuno-sorbent assay (ELISA), recombinant immunoblot assay (RIBA) or polymerase chain reaction (PCR) for the diagnosis of HCV. Furthermore, studies published between January 2000 and March 2018 were selected.

Exclusion criteria: Studies were excluded if they were designed as clinical trials, recruitng TB patients who were also HIV positive, containing overlapping data or studies whose data were not sufficiently detailed to estimate the prevalence rate.

Two researchers independently reviewed titles and abstracts of studies for eligibility. After selecting the studies, the full texts were reviewed. If there was a disagreement between the two independent researchers for the selection of the studies, a third person was involved as a final referee, and the discussion was solved. Selection of studies was performed using the EndNote X8 software.

Data extraction: From the included articles, we obtained the following information: name of first author, year of publication, country, geographical setting/background based on the continent in which the investigation was conducted, mean age of participants, diagnostic test utilized, sample size, number of TB participants with $\mathrm{HCV}$, prevalence estimates, type of TB patients (suffering from latent or active TB), and level of income based on the definition of the World Bank.

Risk assessment: Internal and external validity, response rate and generalization were used to evaluate the results of the studies using the Hoy et 
al criterion (17). This criterion consists of 10 items that are evaluated based on 'Yes' and 'No' answers. For each answer of 'Yes', one point is given and for each answer of 'No' score is assigned. Based on the points obtained, the studies were divided into three categories. Studies which obtained 0 to 4 points were deemed as at high risk, 5 to 7 points at moderate risk and 8 to 10 at low risk.

Statistical analysis: All data were analyzed using the commercial software Stata Ver.12 (Stata Corp, College Station, TX, USA). The overall prevalence of $\mathrm{HCV}$ in patients with $\mathrm{TB}$ was calculated using the random-effect model according to DerSimonian and Laird's approach with 95\% confidence interval (CI) (18). To evaluate heterogeneity, $\mathrm{I}^{2}$ test was used. The values of $25 \%, 50 \%$ and $75 \%$ were considered to indicate low, moderate and high amounts of heterogeneity, respectively (19). Sensitivity analysis was performed to ensure the stability of the results. In this analysis, the effect of omitting each study per time was examined (20). The studies were, then, ranked according to the year of publication and the sample size, and cumulative meta-analysis was performed to determine the effect of these factors on the prevalence of $\mathrm{HCV}$ (21).

In order to examine possible sources of heterogeneity, sub-group analyses were conducted based on the year of study publication, sample size, quality of studies, diagnostic test, geographic background, level of income (based on the definition of the World Bank) and type of TB (active or latent).

Meta-regression was also conducted based on the year of study publication. Egger's test was used to check the publication bias (22). Duval and Tweedie's trim-and-fill method was used to evaluate the effect of potentially missing studies (publication bias), whose effect sizes could possibly modify the estimated prevalence rate of HCV (23).
The Cohen's Kappa coefficient was used for quantitatively assessing the agreement between researchers on the selection of studies, data extraction and methodological quality assessment (24). All figures with two-sided P-value $<0.05$ were considered as statistically significant.

\section{RESULTS}

Study selection: Reporting of the results of this systematic review and meta-analytical study was carried out in accordance with the "Preferred Reporting Items for Systematic Reviews and Meta-analyses" (PRISMA) guidelines (25). The process of selecting studies is pictorially presented in Figure 1.

In the initial search, 535 studies were identified from the different scholarly databases. After removing duplicates, searches led to a pool of 354 studies. After reviewing the title and abstract of the studies, 43 studies remained. The full texts of the studies were reviewed, and 21 were selected for the final analysis based on inclusion/exclusion criteria $(9,26-45)$. The agreement between the two independent researchers was $92.17 \%$ for the selection of studies.

Study and participant characteristics: A total of 15,542 patients with TB participated in the studies. Seven studies were conducted in Europe, 6 studies in Asia, 5 studies in America and 3 studies in Africa. Table 1 shows the main characteristics of the included studies.

Risk of bias within studies: After reviewing the articles, $12(57.14 \%)$ of them were deemed at low risk, $6(28.57 \%)$ had moderate risk and $3(14.29 \%)$ were considered at high risk. The agreement between the two independent researchers was $84.26 \%$ for risk assessment.

The pooled prevalence of $\mathrm{HCV}$ in TB patients: The prevalence of $\mathrm{HCV}$ in TB patients was $2 \%$ to $27 \%$. Based on the random-effect model, the overall prevalence was $7 \%$ [95\% CI: 6-9]. The heterogeneity was high between studies ( $\mathrm{I}=94.2 \% ; \mathrm{P}<0.0001)$ (Figure 2). 

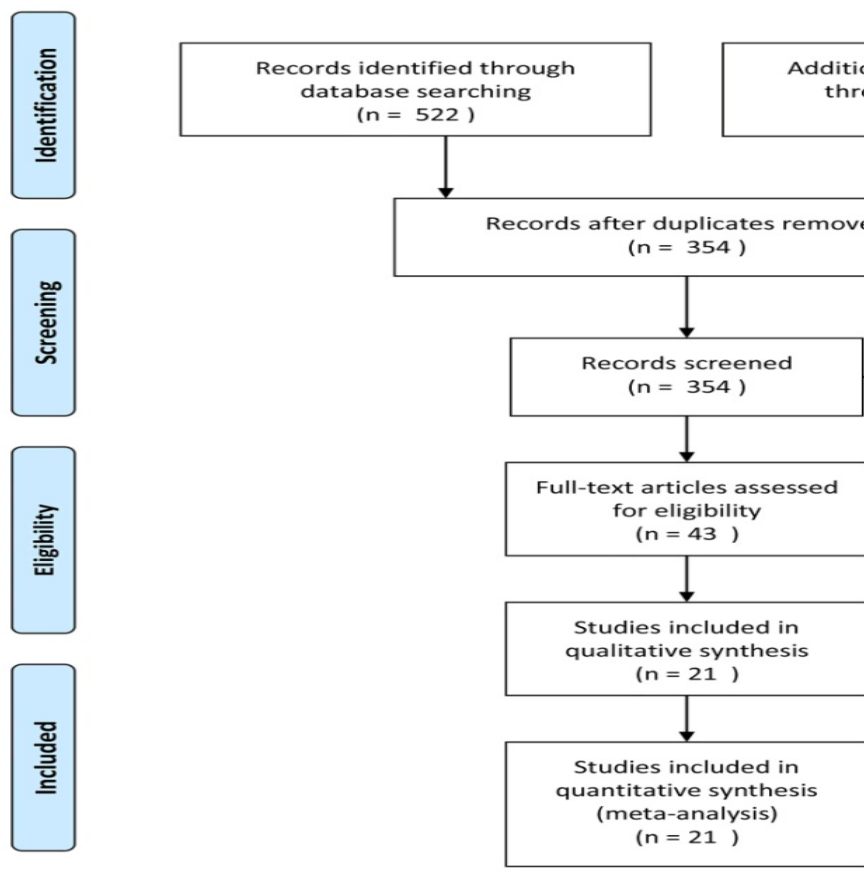

dditional records identified through other sources atabase searching $(n=13)$ $(\mathrm{n}=354)$
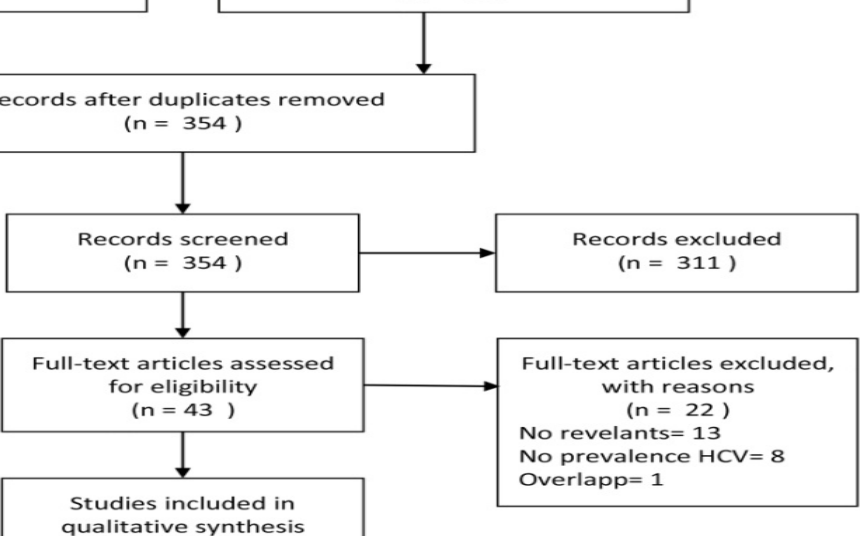

Figure 1: Flowchart of study selection

Study

ID

Richards (2006)

Kuniholm (2008)

Pando (2008)

Khalili (2009)

Khan (2010)

Chien (2010)

Wang (2011)

Reis (2011)

Badawy (2011)

Lomtadze (2013)

Akhtar (2013)

Beasley (2013)

Zhang (2013)

Potter (2014)

Campo (2014)

Agha (2015)

Ahmadi Nooredinvand (2015)

Abdallah (2015)

Bushnell (2015)

Merza (2016)

Costi (2017)

Overall ( $($-squared $=94.2 \%, p=0.000$ )

NOTE: Weights are from random effects analysis

$-.361$
Prevalence (95\% CI)

$0.22(0.17,0.27) \quad 3.70$

$0.12(0.08,0.16)$

$0.12(0.07,0.16) \quad 3.92$

$0.27(0.19,0.36) \quad 1.98$

$0.02(0.00,0.04) \quad 5.89$

$0.10(0.06,0.13) \quad 4.78$

$0.07(0.04,0.09)$

$0.07(0.05,0.10) \quad 5.38$

$0.16(0.09,0.22) \quad 3.03$

$0.21(0.16,0.25) \quad 4.06$

$0.09(0.04,0.14) \quad 3.45$

$0.03(0.01,0.06) \quad 5.45$

$0.04(0.03,0.05)$

$0.02(0.00,0.04) \quad 6.00$

$0.04(0.03,0.05)$

$0.17(0.09,0.25)$

$0.02(0.00,0.03) \quad 6.18$

$0.01(-0.01,0.03)$

$0.02(0.02,0.03)$

$0.00(-0.00,0.01) \quad 6.29$

$0.20(0.13,0.26) \quad 2.78$

$0.07(0.06,0.09) \quad 100.00$

Figure 2: Prevalence of HCV in TB patients with 95\% confidence interval for each included study

DOI: http://dx.doi.org/10.4314/ejhs.v29i1.17 
Results of subgroup analysis: The prevalence rates based on the diagnostic test, sample size, geographical background, risk assessment of the study and gender of the participants are shown in Table 2.

Table 1: Characteristics of the included studies

\begin{tabular}{ccccccc}
\hline First author & Year & Country & Age $($ Mean \pm SD) & Test & Prevalence & No. of participants \\
\hline Richards & 2006 & Georgia & 35 & ELISA & $22 \%$ & 272 \\
Kuniholm & 2008 & Georgia & NA & ELISA & $12.00 \%$ & 300 \\
Pando & 2008 & Argentina & $34.8 \pm 14.1$ & ELISA & $11.80 \%$ & 187 \\
Khalili & 2009 & Iran & $43.21 \pm 18.27$ & ELISA & $27.45 \%$ & 102 \\
Khan & 2010 & UK & NA & ELISA & $2.00 \%$ & 245 \\
Chien & 2010 & Taiwan & NA & ELISA & $10 \%$ & 295 \\
Wang & 2011 & Taiwan & NA & PCR & $6.70 \%$ & 360 \\
Reis & 2011 & Brazil & NA & ELISA & $7.50 \%$ & 402 \\
Badawy & 2011 & Egypt & NA & ELISA & $6.40 \%$ & 135 \\
Lomtadze & 2013 & Georgia & $21-92$ & ELISA & $21 \%$ & 326 \\
Akhtar & 2013 & Pakistan & $42 \pm 18.2$ & ELISA & $9.10 \%$ & 110 \\
Beasley & 2013 & UK & NA & ELISA & NA & 192 \\
Zhang & 2013 & China & NA & ELISA & $3.80 \%$ & 2296 \\
Potter & 2014 & UK & $37.7 \pm 15.3$ & ELISA & $2.00 \%$ & 302 \\
Campo & 2014 & USA & NA & ELISA & $3.60 \%$ & 1421 \\
Agha & 2015 & Egypt & NA & PCR & $17.02 \%$ & 94 \\
Ahmadi Nooredinvand & 2015 & UK & NA & ELISA & $1.60 \%$ & 429 \\
Abdallah & 2015 & Sudan & $36.03 \pm 13.3$ & ELISA & $1 \%$ & 98 \\
Bushnell & $201+5$ & USA & NA & ELISA & $4.20 \%$ & 7624 \\
Merza & 2016 & Iraq & $40.34 \pm 20.29$ & ELISA & $0.90 \%$ & 214 \\
Costi & 2017 & Brazil & $38.0 \pm 12.9$ & PCR & $20 \%$ & 138 \\
\hline
\end{tabular}

Diagnostic test: ELISA tests were used to detect $\mathrm{HCV}$ in 13 studies, with a prevalence of $7 \%$ [95\%CI: 5-8]. PCR tests were performed in 3 studies with a prevalence of $14 \%$ [95\% CI: 23-23]. This difference was statistically significant $(\mathrm{P}=0.0039)$.

Sample size: The estimated prevalence in studies with a sample size of less than or equal to 250 participants was higher $(9 \%$ [95\%CI: 6-9]) compared to studies with a sample size greater than 250 (7\% [95\%CI: 5-9]). However, this difference was not statistically significant.

Geographical background: The highest prevalence was found in Africa $(11 \%$ [95\%CI: 123]), followed by Europe (9\% [95\%CI: 4-13]), America (7\% [95\%CI: 4-10]) and Asia (7\%
[95\%CI: 4-11]). This difference was statistically significant $(\mathrm{P}=0.0076)$.

Risk of bias: The prevalence stratified according to the risk of bias was $9 \%$ [95\%CI: 11-7] in 12 studies at low risk of bias, 9\% [95\%CI: 13-4] in 6 studies at moderate risk, and $2 \%$ [95\% CI: $1-3$ ] in studies at high risk. These differences were not significant.

Prevalence of $\mathrm{HCV}$ and gender: The prevalence rate of $\mathrm{HCV}$ in $\mathrm{TB}$ men was collected from 8 studies $(10 \%$ [95\%CI: 14-16]) and in women from other 8 studies (2\% [95\%CI: 1-4]). This difference was statistically significant $(\mathrm{P}=0.0672)$. This finding showed that men had a higher risk for $\mathrm{HCV}$ than women (Odds Ratio, $\mathrm{OR}=2.02$ [95\%CI: 1.28-3.18]) (Figure 3). 
Table 2: Subgroup analyses of prevalence of HCV in TB patients. Abbreviations: ns (not statistically significant).

\begin{tabular}{|c|c|c|c|c|c|c|}
\hline \multirow[t]{2}{*}{ Variables } & \multirow{2}{*}{$\begin{array}{l}\text { No. of } \\
\text { studies }\end{array}$} & \multirow{2}{*}{$\begin{array}{c}\text { No. of } \\
\text { participants }\end{array}$} & \multirow{2}{*}{$\begin{array}{c}\text { Pooled } \\
\text { prevalence } \\
(95 \% \mathrm{CI})\end{array}$} & \multicolumn{2}{|c|}{ Heterogeneity value } & \multirow[t]{2}{*}{$P$ value } \\
\hline & & & & $I^{2}(\%)$ & $P$ value & \\
\hline Diagnostic test & & & & & & 0.0039 \\
\hline ELISA & 18 & 14950 & $7 \%(5-8)$ & $94.3 \%$ & $<0.0001$ & \\
\hline PCR & 3 & 592 & $14 \%(5-23)$ & $88.4 \%$ & $<0.0001$ & \\
\hline Sample size & & & & & & $<0.0001$ \\
\hline$\leq 250$ & 10 & 1515 & $9 \%(6-9)$ & $93.1 \%$ & $<0.0001$ & \\
\hline$>250$ & 11 & 14027 & $7 \%(5-9)$ & $95.2 \%$ & $<0.0001$ & \\
\hline $\begin{array}{l}\text { Geographical } \\
\text { background }\end{array}$ & & & & & & 0.0076 \\
\hline Africa & 3 & 327 & $11 \%(1-23)$ & $93.9 \%$ & $<0.0001$ & \\
\hline Asia & 6 & 3377 & $7 \%(4-11)$ & $94.6 \%$ & $<0.0001$ & \\
\hline America & 5 & 9772 & $7 \%(4-10)$ & $93.5 \%$ & $<0.0001$ & \\
\hline Europa & 7 & 2066 & $9 \%(4-13)$ & $96.0 \%$ & $<0.0001$ & \\
\hline Risk of bias & & & & & & $<0.0001$ \\
\hline Low & 12 & 13742 & $9 \%(7-11)$ & $95.5 \%$ & $<0.0001$ & \\
\hline Moderate & 6 & 1061 & $9 \%(4-13)$ & $94.3 \%$ & $<0.0001$ & \\
\hline High & 3 & 739 & $2 \%(1-3)$ & $0.0 \%$ & $\mathrm{~ns}$ & \\
\hline Gender & & & & & & 0.0672 \\
\hline Male & 8 & 5821 & $10 \%(6-14)$ & $94.1 \%$ & $<0.0001$ & \\
\hline Female & 8 & 3838 & $3 \%(1-4)$ & $74.0 \%$ & $<0.0001$ & \\
\hline Level of income & & & & & & $<0.0001$ \\
\hline Lower middle & 7 & 1335 & $14 \%(6-21)$ & $95.3 \%$ & $<0.0001$ & \\
\hline Upper middle & 6 & 3339 & $9 \%(6-13)$ & $95.6 \%$ & $<0.0001$ & \\
\hline High & 8 & 10868 & $3 \%(2-4)$ & $81.3 \%$ & $<0.0001$ & \\
\hline Type of TB & & & & & & $<0.0001$ \\
\hline Active & 18 & 14676 & $9 \%(7-10)$ & $95.0 \%$ & $<0.0001$ & \\
\hline $\begin{array}{l}\text { Both (Active and } \\
\text { latent) }\end{array}$ & 3 & 866 & $2 \%(1-3)$ & $0.0 \%$ & ns & \\
\hline
\end{tabular}

DOI: http://dx.doi.org/10.4314/ejhs.v29i1.17 


\begin{tabular}{|c|c|c|c|}
\hline Study or Subgroup & $\begin{array}{c}\text { Male } \\
\text { Events Total }\end{array}$ & $\begin{array}{c}\text { Female } \\
\text { Events Total }\end{array}$ & Weight M \\
\hline Abdallah 2015 & 070 & 120 & $1.9 \%$ \\
\hline Ahmadi Nooredimvand 2015 & 6220 & 1209 & $4.0 \%$ \\
\hline Bushnell 2015 & $127 \quad 4546$ & 493078 & $29.0 \%$ \\
\hline Chien 2010 & $19 \quad 192$ & 10103 & $16.5 \%$ \\
\hline Pando 2008 & $21 \quad 123$ & 164 & $4.3 \%$ \\
\hline Reis 2011 & $25 \quad 289$ & $5 \quad 113$ & $13.1 \%$ \\
\hline Richards 2006 & $50 \quad 197$ & 1175 & $18.5 \%$ \\
\hline Wang 2011 & 19184 & $5 \quad 176$ & $12.7 \%$ \\
\hline Total $(95 \% \mathrm{Cl})$ & \multicolumn{2}{|l|}{5821} & $100.0 \%$ \\
\hline Total events & 267 & 83 & \\
\hline $\begin{array}{l}\text { Heterogeneity: Tau }{ }^{2}=0.16 ; 0 \\
\text { Test for overall effect: } z=3.0\end{array}$ & $\begin{array}{l}i^{2}=12.45, d f= \\
(P=0.002)\end{array}$ & $=0.09)_{1} 1^{2}$ & \\
\hline
\end{tabular}

Odds Ratio

Odds Ratio

-, Random, $95 \%$ Cl M-H, Random, $95 \% \mathrm{Cl}$

Study or Subgroup

$0.09[0.00,2.35]$

5

$5.83[0.70,48.86]$

$1.78[1.27,2.48]$

$1.02[0.46,2.29]$

$12.97[1.70,98.81]$

$2.05[0.76,5.48]$

$1.98[0.97,4.05]$

$3.94[1.44,10.79]$

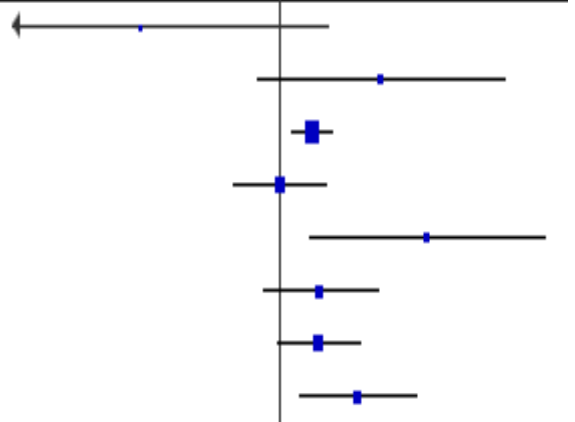

Figure 3: Meta-analysis of the Odds Ratio (OR) for prevalence of HCV in TB patients in male subjects compared to female individuals

Level of income: The prevalence of $\mathrm{HCV}$ in $\mathrm{TB}$ was $14 \%$ [95\% CI: 6-21] in lower middle income settings, 9\% [95\%CI: 6-13] in upper middle income contexts and 3\% [95\%CI: 2-4] in high income countries.

Type of TB: The prevalence was $9 \%$ [95\%CI: 7 $10]$ in studies with active TB patients and $2 \%$ [95\%CI: 1-3] in studies with active or latent TB patients.

Meta-regression: The prevalence of $\mathrm{HCV}$ in TB patients was assessed based on the published years, and significant changes were observed $(\mathrm{P}=0.049)$.

Sensitivity analysis: By omitting each study, its effect on the overall prevalence rate was evaluated, and the sensitivity analysis indicated that the results before and after did not change in a significant way, which indicates the stability of the results.

Cumulative meta-analysis: Cumulative metaanalysis was performed by sorting studies based on the year of publication and sample size. When the studies were sorted according to the year of publication, their $95 \%$ CI during the years of study release revealed an increase in the rate of $\mathrm{HCV}$ in TB patients. Also, when studies were sorted according to sample size, $95 \%$ CI showed a decrease in the rate of $\mathrm{HCV}$ in TB patients.

Publication bias: Publication bias was computed performing the Egger's regression test, and the results indicated a bias in published studies $(\mathrm{P}=0.000)$. Due to this bias, the Trim and Fill test was performed and found 7 censored studies and their potential effects on the prevalence rate.

Risk factors for $\mathrm{HCV}$ in TB: Some selected studies identified the risk factors for $\mathrm{HCV}$ in TB patients. These risk factors included: history of sexually transmitted infections (STIs), tattoo and body piercing, history of prison or correctional services, history of injection drugs use (IDU), history of surgery, blood transfusion, dental services, smoking, alcohol consumption, family history of hepatitis $\mathrm{C}$, use of personal objects belonging to others, and being homeless.

\section{DISCUSSION}

To the best of our knowledge, this study is the first meta-analysis to comprehensively address the prevalence of $\mathrm{HCV}$ in TB patients worldwide. A total of 21 studies were selected using a comprehensive search strategy in validated databases. The sensitivity analysis confirmed that

DOI: http://dx.doi.org/10.4314/ejhs.v29i1.17 
the results were stable. The cumulative metaanalysis, based on the year of publication revealed a decrease in the rate of HCV.

The prevalence of $\mathrm{HCV}$ in $\mathrm{TB}$ patients reported in this study was higher than the incidence of $\mathrm{HCV}$ in HIV positive patients according to some studies of the literature $(46,47)$. Also, the prevalence in this study is higher than the incidence of $\mathrm{HCV}$ in the general population, according to a recent meta-analytical study (48). On the other hand, when compared to hemodialysis patients, the prevalence of $\mathrm{HCV}$ in TB patients was found to be lower (49).

An increasingly rising prevalence rate of TB worldwide has led the WHO to propose a DOTSbased approach. This strategy, which treats patients for 6 months, is the most effective, practical and proper way to treat the disease $(50,51)$.

Estimates of hepatotoxicity induced by Rifampicin, Isoniazid and Pyrazamide are difficult to compute due to variability among patients in terms of physical and psychological characteristics. Chronic liver diseases, such as viral infections, can increase hepatotoxicity (5254). In TB patients with hepatitis $C$, the risk of hepatotoxicity is higher than that of TB patients who do not suffer from hepatitis $C(11,55)$. Studies show that HCV infection in TB patients can cause a significant change in the number of $\mathrm{T}$ CD4 + lymphocytes (56-58). In patients with TB, $\mathrm{HCV}$ levels increase the concentrations of liver enzymes. However, there is still no clear relationship between $\mathrm{HCV}$ and increased risk of hepatotoxicity (56-58).

Our findings showed that the reported prevalence was significantly different depending on the diagnostic tests used: the geographical background, the highest prevalence of HCV in TB patients was observed in African countries. The health conditions of countries play an important role in the spread of various diseases, including HCV and TB. Public health and health care services have problems to be delivered programs major impact on the prevalence of infectious diseases in these countries.
In many countries, including developing countries, many public health officials are unaware of the impact of infectious diseases, and, unfortunately, do not provide the right conditions for screening and healthcare (63). In previous studies, there is little information about the difference between social, health, cultural and economic backgrounds. These differences should be noticed in future studies.

The findings of this study showed that the prevalence of $\mathrm{HCV}$ in male $\mathrm{TB}$ patients was higher than that in women $(\mathrm{RR}=1.89)$. In studies, high risk behaviors were reported in men more than in women, which made them being more at risk for $\mathrm{HCV}$. Some studies have shown that behaviors such as IDU, the use of common syringes, tattoos, body piercing and alcohol consumption were higher in men than in women, and, consequently, the prevalence rate of $\mathrm{HCV}$ was higher $(64,65)$.

Meta-regression according to the year of publication of studies indicated a reduction in the rate of $\mathrm{HCV}$ in $\mathrm{TB}$ patients. This can be due to several factors. Over the past decades, better health conditions and wider access to health services worldwide have improved for prevention and control of HCV. Screening and training in high-risk groups (drug users, prisoners) and special populations by the health system in various countries has, also, significantly and positively impacted on the control and management of infectious diseases (66).

The risk factors for $\mathrm{HCV}$ in $\mathrm{TB}$ patients that have been reported by selected studies are among the most recognized risk factors mentioned in various studies in the world. Health decision- and policy-makers and primary healthcare providers must implement special programs for people at risk. Paying attention to these people reduces significantly the prevalence of the disorder (67-69).

However, despite some strengths, including its novelty and the broad and comprehensive search strategy, this study has the following limitations:

DOI: http://dx.doi.org/10.4314/ejhs.v29i1.17 
a. Due to the fact that there is a methodological diversity among the studies, there is a significant heterogeneity in this metaanalysis, which could affect results and their generalization.

b. In many parts of the world, studies have not been conducted, which could impact on the overall estimated prevalence rate of $\mathrm{HCV}$ in TB patients.

c. Diagnostic tests used in studies, gender and geographic context as potential heterogeneity sources and bias observed in studies make it possible to interpret the results with caution.

Taking the above-mentioned shortcomings into account, the results of this study highlighted the importance of performing HCV screening in TB patients. Knowing whether $\mathrm{HCV}$ is present or not in these patients can be helpful in effectively treating them. Healthcare decision- and policymakers need to implement ad hoc measures to educate and screen groups at high risk for developing $\mathrm{HCV}$ and $\mathrm{TB}$.

\section{ACKNOWLEDGMENTS}

We are grateful to Dr. Homie Razavi and Dr. Behzad Hajarizadeh for their comments and advise on earlier versions of this paper.

\section{REFERENCES}

1. Kizza FN, List J, Nkwata AK, Okwera A, Ezeamama AE, Whalen CC, et al. Prevalence of latent tuberculosis infection and associated risk factors in an urban African setting. $B M C$ Infect Dis. 2015;15:165.

2. Sharma A, Hill A, Kurbatova E, van der Walt M, Kvasnovsky C, Tupasi TE, et al. Estimating the future burden of multidrugresistant and extensively drug-resistant tuberculosis in India, the Philippines, Russia, and South Africa: a mathematical modelling study. Lancet Infect Dis. 2017;17(7):707-15.

3. WHO. Global tuberculosis report 20172017 [Available from: http://www.who.int/tb/publications/global_re port/en/.
4. Stanaway JD, Flaxman AD, Naghavi M, Fitzmaurice C, Vos T, Abubakar I, et al. The global burden of viral hepatitis from 1990 to 2013: findings from the Global Burden of Disease Study 2013. Lancet. 2016;388(10049):1081-8.

5. Gower E, Estes C, Blach S, Razavi-Shearer $\mathrm{K}$, Razavi H. Global epidemiology and genotype distribution of the hepatitis $\mathrm{C}$ virus infection. J Hepatol. 2014;61(1 Suppl):S45S57.

6. Rantala M, van de Laar MJ. Surveillance and epidemiology of hepatitis B and C in Europe a review. Euro Surveill. 2008;13(21):18880.

7. Messina JP, Humphreys I, Flaxman A, Brown A, Cooke GS, Pybus OG, et al. Global distribution and prevalence of hepatitis C virus genotypes. Hepatology. 2015;61(1):7787.

8. Lorent N, Sebatunzi O, Mukeshimana G, Van den Ende J, Clerinx J. Incidence and risk factors of serious adverse events during antituberculous treatment in Rwanda: a prospective cohort study. PLoS One. 2011;6(5):e19566.

9. Bushnell G, Stennis NL, Drobnik AM, Proops $\mathrm{DC}$, Ahuja SD, Bornschlegel $\mathrm{K}$, et al. Characteristics and TB treatment outcomes in TB patients with viral hepatitis, New York City, 2000-2010. Epidemiol Infect. 2015;143(9):1972-81.

10. Kim WS, Lee SS, Lee CM, Kim HJ, Ha CY, Kim HJ, et al. Hepatitis C and not hepatitis B virus is a risk factor for anti-tuberculosis drug induced liver injury. BMC Infect Dis. 2016;16:50.

11. Yew WW, Leung CC. Antituberculosis drugs and hepatotoxicity. Respirology. 2006;11(6):699-707.

12. Schechter M, Zajdenverg R, Falco G, Barnes GL, Faulhaber JC, Coberly JS, et al. Weekly rifapentine/isoniazid or daily rifampin/pyrazinamide for latent tuberculosis in household contacts. Am J Respir Crit Care Med. 2006;173(8):922-6.

13. Dye C. Global epidemiology of tuberculosis. Lancet. 2006;367(9514):938-40.

14. Kunimoto D, Warman A, Beckon A, Doering D, Melenka L. Severe Hepatotoxicity

DOI: http://dx.doi.org/10.4314/ejhs.v29i1.17 
Associated with Rifampin-Pyrazinamide Preventative Therapy Requiring Transplantation in an Individual at Low Risk for Hepatotoxicity. Clin Infect Dis. 2003;36(12):e158-61.

15. van Hest R, Baars $H$, Kik $S$, van Gerven $P$, Trompenaars MC, Kalisvaart $\mathrm{N}$, et al. Hepatotoxicity of rifampin-pyrazinamide and isoniazid preventive therapy and tuberculosis treatment. Clin Infect Dis. 2004;39(4):488-96.

16. Forget EJ, Menzies D. Adverse reactions to first-line antituberculosis drugs. Expert Opin Drug Saf. 2006;5(2):231-49.

17. Hoy D, Brooks P, Woolf A, Blyth F, March $\mathrm{L}$, Bain $\mathrm{C}$, et al. Assessing risk of bias in prevalence studies: modification of an existing tool and evidence of interrater agreement. $J$ Clin Epidemiol. 2012;65(9):934-9.

18. DerSimonian R, Laird N. Meta-analysis in clinical trials. Control Clin Trials. 1986;7(3):177-88.

19. Higgins JP, Thompson SG. Quantifying heterogeneity in a meta-analysis. Stat Med. 2002;21(11):1539-58.

20. Thakkinstian A, McElduff P, D'Este C, Duffy D, Attia J. A method for meta-analysis of molecular association studies. Stat Med. 2005;24(9):1291-306.

21. Mullen B, Muellerleile P, Bryant B. Cumulative Meta-Analysis: A Consideration of Indicators of Sufficiency and Stability. Pers Soc Psychol Bull .2001;27(11).1450-62.

22. Egger M, Davey Smith G, Schneider M, Minder C. Bias in meta-analysis detected by a simple, graphical test. BMJ. 1997;315(7109):629-34.

23. Duval S, Tweedie R. Trim and fill: a simple funnel-plot-based method of testing and adjusting for publication bias in metaanalysis. Biometrics. 2000;56(2):455-63.

24. Viera AJ, Garrett JM. Understanding interobserver agreement: the kappa statistic. Fam Med. 2005;37(3):360-3.

25. Liberati A, Altman DG, Tetzlaff J, Mulrow C, Gotzsche PC, Ioannidis JP, et al. The PRISMA statement for reporting systematic reviews and meta-analyses of studies that evaluate healthcare interventions: explanation and elaboration. BMJ. 2009;339:b2700.

26. Abdallah TM, Idriss MI, Ahmed AM, Ali AA, Saeed OK. Sero-Prevalence of Hepatitis $B$ and Hepatitis C Viruses among Tuberculosis Patients in Kassala, Eastern Sudan. Glob $J$ Infect Dis Clin Res. 2015;1(1):001-3.

27. Agha MA, El-Mahalawy II, Seleem HM, Helwa MA. Prevalence of hepatitis $\mathrm{C}$ virus in patients with tuberculosis and its impact in the incidence of anti-tuberculosis drugs induced hepatotoxicity. Egypt $J$ Chest Dis Tuberc. 2015;64(1):91-6.

28. Akhtar J, Qamar MU, Hakeem A, Waheed A, Sarwar F, Anwar J. Sero-prevalence of HBV and HCV in tuberculous patients at Sheikh Zayed hospital Rahim Yar khan, Pakistan. Biomedica. 2013;29:69-72.

29. Badawy M, Taha M, Mohamed L, Fathy A. Hepatitis C virus infection among tuberculosis patients in Sohag Governorate: Seroprevalence and associated risk factors. Eur Respir J. 2011;38(Suppl 55):4896.

30. Beasley VE, Anders R, Darmalingam M. Retrospective study to assess the background incidence of Hepatitis B and C in patients with Tuberculosis and latent tuberculosis at Whipps Cross Hospital. Thorax. 2013;68(Suppl 3):A117-A8.

31. Campo M, Shrestha A, Oren E, Thiede H, Duchin J, Narita M, et al. Characterization of hepatitis $\mathrm{C}$ infection in tuberculosis patients in an urban city in the USA. Epidemiol Infect. 2014;142(7):1459.

32. Chien JY, Huang RM, Wang JY, Ruan SY, Chien YJ, Yu CJ, et al. Hepatitis $\mathrm{C}$ virus infection increases hepatitis risk during antituberculosis treatment. Int $J$ Tuberc Lung Dis. 2010;14(5):616.

33. Costi C, Grandi T, Halon ML, Silva MS, Silva CM, Gregianini TS, et al. Prevalence of hepatitis $\mathrm{C}$ virus and human immunodeficiency virus in a group of patients newly diagnosed with active tuberculosis in

DOI: http://dx.doi.org/10.4314/ejhs.v29i1.17 
Porto Alegre, Southern Brazil. Mem Inst Oswaldo Cruz. 2017;112(4):255-9.

34. Khalili H , Dashti-Khavidaki S, Rasoolinejad M, Rezaie L, Etminani M. Anti-tuberculosis drugs related hepatotoxicity; incidence, risk factors, pattern of changes in liver enzymes and outcome. Daru. 2009;17(3):163-67.

35. Khan S, Asgheddi M, Abdullah M, O'Donoghue M, Lalvani A, Campbell L, et al. Prevalence of viral hepatitis in patients undergoing anti-tuberculosis therapy in West London. Gut. 2010;59(Suppl 2):A42.

36. Kuniholm MH, Mark J, Aladashvili M, Shubladze N, Khechinashvili G, Tsertsvadze $\mathrm{T}$, et al. Risk factors and algorithms to identify hepatitis C, hepatitis B, and HIV among Georgian tuberculosis patients. Int $J$ Infect Dis. 2008;12(1):51-6.

37. Lomtadze N, Kupreishvili L, Salakaia A, Vashakidze S, Sharvadze L, Kempker RR, et al. Hepatitis $\mathrm{C}$ virus co-infection increases the risk of anti-tuberculosis drug-induced hepatotoxicity among patients with pulmonary tuberculosis. PLoS One. 2013;8(12):e83892.

38. Merza MA, Haji SM, Alsharafani AM, Muhammed SU. Low prevalence of hepatitis $\mathrm{B}$ and $\mathrm{C}$ among tuberculosis patients in Duhok Province, Kurdistan: Are HBsAg and anti-HCV prerequisite screening parameters in tuberculosis control program?. Int $J$ Mycobacteriol. 2016;5(3):313-7.

39. Nooredinvand HA, Connell DW, Asgheddi M, Abdullah M, O'Donoghue M, Campbell L, et al. Viral hepatitis prevalence in patients with active and latent tuberculosis. World $J$ Gastroenterol. 2015;21(29):8920-6.

40. Pando MA, De Salvo C, Bautista CT, Eyzaguirre L, Carrion G, Feola M, et al. Human immunodeficiency virus and tuberculosis in Argentina: prevalence, genotypes and risk factors. $J$ Med Microbiol. 2008;57(Pt 2):190-7.

41. Potter JL, Hyams C, Shaukat M, Babiker ZO, Macavei VM, Jayasekera N, et al. Should Screening For Chronic Viral Hepatitis In Patients With Tuberculosis Be Introduced To Nice Guidelines?. Thorax. 2014;69(Suppl 2):A159.
42. Reis NR, Lopes CL, Teles SA, Matos MA, Carneiro MA, Marinho TA, et al. Hepatitis C virus infection in patients with tuberculosis in Central Brazil. Int $J$ Tuberc Lung Dis. 2011;15(10):1397-402.

43. Richards DC, Mikiashvili T, Parris JJ, Kourbatova EV, Wilson JC, Shubladze N, et al. High prevalence of hepatitis $\mathrm{C}$ virus but not HIV co-infection among patients with tuberculosis in Georgia. Int $J$ Tuberc Lung Dis. 2006;10(4):396.

44. Wang JY, Liu CH, Hu FC, Chang HC, Liu JL, Chen JM, et al. Risk factors of hepatitis during anti-tuberculous treatment and implications of hepatitis virus load. $J$ Infect. 2011;62(6):448-55.

45. Zhang L, Zhang D, Chen W, Zou X, Ling L. High prevalence of HIV, HCV and tuberculosis and associated risk behaviours among new entrants of methadone maintenance treatment clinics in Guangdong Province, China. PLoS One. 2013;8(10):e76931.

46. Platt L, Easterbrook P, Gower E, McDonald B, Sabin K, McGowan C, et al. Prevalence and burden of $\mathrm{HCV}$ co-infection in people living with HIV: a global systematic review and meta-analysis. Lancet Infect Dis. 2016;16(7):797-808.

47. Azevedo TCL, Zwahlen M, Rauch A, Egger M, Wandeler G. Hepatitis C in HIV-infected individuals: a systematic review and metaanalysis of estimated prevalence in Africa. $J$ Int AIDS Soc. 2016;19(1):20711.

48. Mohd Hanafiah K, Groeger J, Flaxman AD, Wiersma ST. Global epidemiology of hepatitis $\mathrm{C}$ virus infection: new estimates of age-specific antibody to HCV seroprevalence. Hepatology. 2013;57(4):1333-42.

49. Harfouche M, Chemaitelly H, Mahmud S, Chaabna K, Kouyoumjian SP, Al Kanaani Z, et al. Epidemiology of hepatitis $\mathrm{C}$ virus among hemodialysis patients in the Middle East and North Africa: systematic syntheses, meta-analyses, and meta-regressions. Epidemiol Infect. 2017;145(15):3243-63.

50. Obermeyer Z, Abbott-Klafter J, Murray CJL. Has the DOTS Strategy Improved Case

DOI: http://dx.doi.org/10.4314/ejhs.v29i1.17 
Finding or Treatment Success? An Empirical Assessment. PLoS One. 2008;3(3):e1721.

51. Raviglione MC, Uplekar MW. WHO's new Stop TB Strategy. Lancet. 2006;367(9514):952-5.

52. Lee BH, Koh WJ, Choi MS, Suh GY, Chung MP, Kim H, et al. Inactive hepatitis B surface antigen carrier state and hepatotoxicity during antituberculosis chemotherapy. Chest 2005;127(4):1304-11.

53. Hwang SJ, Wu JC, Lee CN, Yen FS, Lu CL, Lin TP, et al. A prospective clinical study of isoniazid-rifampicin-pyrazinamide-induced liver injury in an area endemic for hepatitis B. J Gastroenterol Hepatol. 1997;12(1):87-91.

54. Amarapurkar DN, Prabhudesai PP, Kalro RH, Desai HG. Antituberculosis drug-induced hepatitis and HBsAg carriers. Tuber Lung Dis. 1993;74(3):215-6.

55. Ramappa V, Aithal GP. Hepatotoxicity Related to Anti-tuberculosis Drugs: Mechanisms and Management. $J$ Clin Exp Hepatol. 2013;3(1):37.

56. Kwon YS, Koh WJ, Suh GY, Chung MP, Kim H, Kwon OJ. Hepatitis C virus infection and hepatotoxicity during antituberculosis chemotherapy. Chest. 2007;131(3):803-8.

57. Fernández-Villar A, Sopeña B, Vázquez R, Ulloa F, Fluiters E, Mosteiro $M$, et al. Isoniazid hepatotoxicity among drug users: the role of hepatitis C. Clin Infect Dis. 2003;36(3):293-8.

58. Ungo JR, Jones D, Ashkin D, Hollender ES, Bernstein D, Albanese AP, et al. Antituberculosis drug-induced hepatotoxicity. The role of hepatitis $\mathrm{C}$ virus and the human immunodeficiency virus. Am J Respir Crit Care Med. 1998;157(6 Pt 1):1871-6.

59. Parry JV, Easterbrook P, Sands AR. One or two serological assay testing strategy for diagnosis of HBV and HCV infection? The use of predictive modelling. BMC Infect Dis. 2017;17(Suppl 1):705.

60. Batool A, Khan MI, Bano KA. Efficacy of immunoassay chromatography test for hepatitis - C antibodies detection. J Ayub Med Coll Abbottabad. 2009;21(3):38-9.

61. 6WHO. Global Report for Research on Infectious Diseases of Poverty 2012 [Available

from:http://whqlibdoc.who.int/publications/20 12/9789241564489 eng.pdf?ua $=1$

62. WHO. Closing the Gap in a Generation: Health Equity Through Action on the Social Determinants of Health 2008 [Available from: http://whqlibdoc.who.int/publications/2008/9 789241563703_eng.pdf

63. Mohamed AA, Elbedewy TA, El-Serafy M, El-Toukhy N, Ahmed W, Ali El Din Z. Hepatitis C virus: A global view. World $J$ Hepatol. 2015;7(26):2676-80.

64. Olmedo DB, Precioso PM, Lugdero-Correia A, da Silva G, dos Santos AMG, Pôrto LC. Exposure source prevalence is associated with gender in hepatitis $\mathrm{C}$ virus patients from Rio de Janeiro, Brazil. Mem Inst Oswaldo Cruz. 2017;112(9):632.

65. Tolmane I, Rozentale B, Keiss J, Arsa F, Brigis G, Zvaigzne A. The prevalence of viral hepatitis $\mathrm{C}$ in Latvia: a population-based study. Medicina (Kaunas). 2011;47(10):53235.

66. Hagan LM, Schinazi RF. Best strategies for global HCV eradication. Liver Int. 2013;33(01):68-79.

67. Buonomo AR, Scotto R, Pinchera B, Coppola $\mathrm{N}$, Monari C, Macera M, et al. Epidemiology and risk factors for hepatitis $\mathrm{C}$ virus genotypes in a high prevalence region in Italy. New Microbiol. 2018;41(1):26-29.

68. Wenger PJ, Rottnek F, Parker T, Crippin JS. Assessment of Hepatitis C Risk Factors and Infection Prevalence in a Jail Population. $\mathrm{Am}$ J Public Health. 2014;104(9):1722-7.

69. He Y, Zhang J, Zhong L, Chen X, Liu HM, Wan LK, et al. Prevalence of and risk factors for hepatitis $\mathrm{C}$ virus infection among blood donors in Chengdu, China. $J$ Med Virol. 2011;83(4):616-21.

DOI: http://dx.doi.org/10.4314/ejhs.v29i1.17 